\title{
Foreign Aid, Institutional Quality and Income Inequality in Developing Countries
}

\author{
Ruhaida Saidon *, Zalina Zainal \\ Department of Economics and Agribusiness, School of Economics, Finance and Banking, Universiti Utara \\ Malaysia
}

\begin{abstract}
This study examines the role of institutional quality as a complementary factor on the effectiveness of sectoral allocations of foreign aid (i.e. aid to social sectors, aid to economic sectors, aid to production sectors and aid to multi sectors) on income inequality in selected foreign aid recipient countries. This study utilizes System-Generalized Method of Moment on a panel data of 50 of foreign aid recipient countries during the period 1995 to 2017. The empirical findings revealed that the interaction variables between sectoral allocations of foreign aid with institutional quality have a negative and statistically significant effect on income inequality during the period of study. This finding indicates that institutional quality is one the conditional factor for the effectiveness of sectoral foreign aid allocations in narrowing income inequality in developing countries.
\end{abstract}

Keywords: Foreign Aid; Institutional Quality; Income Inequality, Dynamic Panel Data

JEL Classification: D3, F35, D63

Paper Type: Research

\section{INTRODUCTION}

Income inequality is one of the most urgent issues, exacerbating poverty, hindering development and undermining the full spectrum of human rights. The inclusion of a standalone goal on inequality in the 2030 agenda for Sustainable Development in goal 10, promises to reduce inequalities both within and between countries. Then, inclusive and sustainable economic growth will only be possible if wealth is shared, and income inequality is addressed (UN, 2015). It has been seen that high growth rates do not always translate into high levels of development. The reason is that there are several other limitations to development such as destruction of the environment, poverty, institutional shortcomings and persisting inequality. The developing countries are particularly more vulnerable because they have insufficient resources to achieve a sustainable future. They need assistance from the developed nations to boost their prosperity. In this respect,

*Corresponding author: E-mail: ruhaida78@gmail.com 
foreign aid plays a vital role. Foreign aid is financial aid given by governments and other agencies to support the economic, environmental, social, and political development of developing countries. It is distinguished from humanitarian aid by focusing on alleviating poverty in the long term, rather than a short term response.

In the history of development economics scholar's, the foreign aid or foreign assistance, which is known as the official development assistance (ODA) is the key factor that fills the financial or investment gap in order to achieve economic growth and alleviate poverty in developing countries. According to Nelson (1956) and Erikson (2005), poor countries have low incomes and savings, which cause them to be caught in a "vicious circle of poverty" or "poverty trap". They experience a "low-level equilibrium trap" where a higher income does not lead to an increase in savings but only results in higher population growth. Thus, foreign aid is one of the important tools to reduce poverty and income inequality by facilitating faster and sustained economic growth via increased saving and investment in developing countries (Harrod and Domar, 1965; Chenery and Strout, 1966; Papanek, 1973; Gulati, 1975; Roemer, 1989; Islam, 1992; Thirlwall, 1999; Sachs et al., 2005).

In the present era of increasing globalisation, it has become of utmost importance to propagate global policies which will make it a positive force, contributing to inclusive and sustainable development. In other words, there is a need for a global partnership to protect the global environment, eradicate poverty and inequality. Theoretically, foreign aid provides necessary assistance to developing nations which is required to preserve their natural resources, increase equity in society and protect the environment. For this reason, many economists believe that aid can be used as a tool to improve the economic performance of a country. Before pursuing policies which will lead developing nations to accept foreign aid, it is important to analyse the effectiveness of such policies empirically. Some countries were able to increase economic growth and achieve development using foreign assistance while others got trapped in a debt crisis and become dependent on foreign resources rather than increasing domestic resource mobilization. There are numerous reasons for bad performance in such nations. According to some studies, bad governance, institutional shortcomings and political instability are among the few of the reasons. There is also some evidence that foreign aid creates dualism and substitute domestic saving rather than complimenting it. In these circumstances, economic growth may not be able to promote development.

Therefore, the study on the effect of foreign aid on income inequality is necessary due to both the destructive consequences of inequality as well as its potential effect on growth and poverty. However, the available research on foreign aid and inequality provides little insight into the nature of the relationship. Studies conducted thus far have found an almost equal share of positive effects (Boone, 1996; Herzer and Nunnenkamp, 2012; Ali and Ahmad, 2013; Pham, 2015) or negative effects (Shaifiullah, 2011; Tezanos et al., 2013) or positive but not significant effects (Layton and Nielson, 2008).

The indicator of income inequality within a country is represented by the Gini Index that runs from 0 (perfect equality) to 100 (complete inequality). Figure 1 illustrates the scatter plots between total ODA disbursements (in constant 2010 US\$, millions) and sectoral allocation ODA with income inequality in selected aid recipient countries for the period 1995 to 2017. 

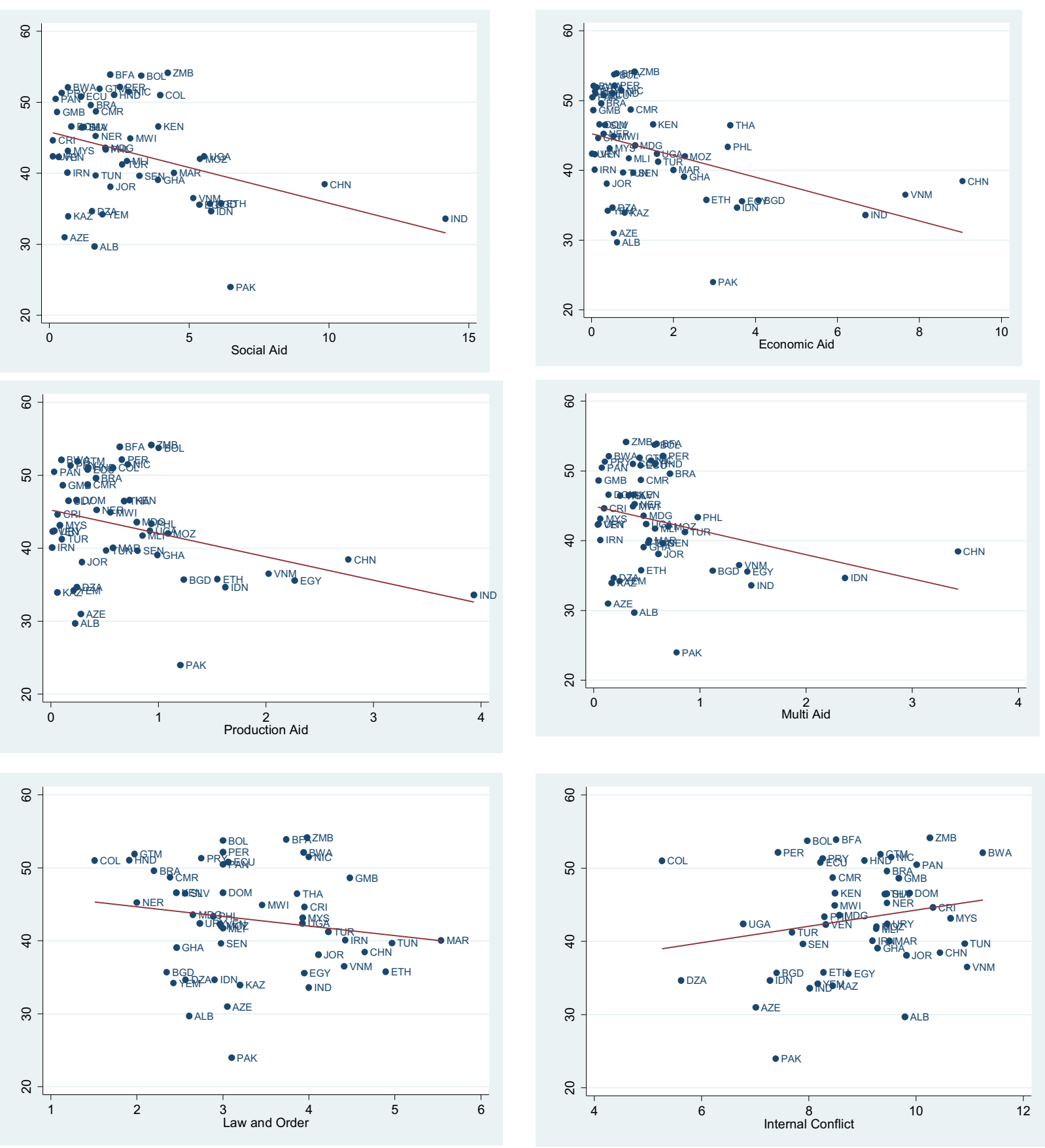

Figure 1. Scatter plot between the sectoral allocation of foreign aid and income inequality Source: Organization of Economic Corporation and Development (2017); Standardized World Income Inequality Database (2017)

Notes: Income inequality proxies by Gini Index and Foreign Aid proxies by Official Development Assistance (ODA)

The scatter plots in Figure 1 show that the sectoral allocations of foreign aid have a negative relationship with the income inequality of the recipient countries. Besides, the scatter plots between the Gini Index and law and order depicted negative relationship with Gini Index. These figures portray that the sectoral allocations of foreign aid and quality of 
institution (law and order) were potentially reducing income inequality in the recipient countries.

\section{LITERATURE REVIEW}

Historically, Friedman (1958) argued that aid was only likely to benefit the political elite. Then, Chase-Dunn (1975) used the Marxist dependency theory to analyze the impact of foreign aid on income inequality. He argued that foreign aid has a positive relationship with income inequality. Bornschier et al. (1978) further discussed the impact of foreign aid on income inequality. Chase-Dunn and Friedman have often concluded that foreign aid is detrimental to overall development (Doucougliagos and Paldam, 2007). Yet, they reach the same conclusion in two very different ways. Marxists tend to blame outside forces, as in dependency theory. At the same time, Friedman pointed towards the effects of what has since been termed fungibility, i.e. that foreign aid often ends up different financing activities than those officially intended (Feyzioghlu, 1998). Friedman also hinted at the general dishonesty of politicians, which is an additional problem when distributing aid resources. There were a few studies related to the foreign aid's impact on inequality with governments' political. The political stream claimed that foreign aid in autocracies tends to be pro-poor, and possibly equality enhancing. Democracy is also thought to affect inequality adversely (Layton \& Nielson, 2009).

All political systems are believed to favour the high-income political elite (Boone, 1997). As such, foreign aid would mean more funds for governing people and the local elite to misappropriate. Aid can be used to maintain and supplement existing disparities in income and political influence. Therefore, (Boone, 1997) deduced that aid has adverse effects on inequality and growth for that matter when it is ineffective due to political misdemeanour. He provided a theoretical discussion of whether foreign aid benefits the poor or mainly benefits political elite, and concluded that his overall findings of the aidgrowth association are consistent with a model where politicians maximize the welfare of wealthy elite.

On the other hand, Calderón et al. (2006) found that there is no robust association between inflows of foreign aid and income inequality as measured by Gini coefficients. The World Development Report (World Bank, 2006a, 2006b) argued that aid does not seem to have to equalize the income distribution. Chong (2004) showed that in poor and relatively unequal societies, democratization tends to be accompanied by a more skewed income distribution while the opposite tends to hold for rich and initially equal societies. Dreher and Gaston (2007) instead, focused on the full world sample and find robust evidence of a positive overall association between democratization and income inequality, i.e. that democratization in general leads to a more skewed distribution. Focusing on third world countries, one might thus expect that democratization lead to more skewed distributions of income, not less. In contrast, the relation between aid and income distribution is ambiguous in general as well as when concentrating on relatively democratic countries. In autocracies, however, such an impact of aid is insignificant (Bjørnskov, 2009).

Layton and Nielson (2009) had examined the relationship between foreign aid and income inequality using dataset includes 82 countries and over 1,100 observations from the year 1975 to 2005. They concluded that the effect of foreign aid on inequality is somewhere between zero and weakly positive (increasing inequality). Calderon and Gradstein (2009) examined the effect of foreign aid on income inequality for the period 1971-2002 using the household surveys data on 111 countries. They had conducted a dynamic panel data technique, which allowed accounting for potential simultaneity and heterogeneity problems. They found some weak evidence that foreign aid is conducive to the improvement of the distribution of income when the quality of institutions is taken into 
account; however, this result is not robust. This finding is consistent with recent empirical research on aid ineffectiveness in achieving economic growth or promoting democratic institutions.

While corruption and poor institutions do appear to bear some responsibility for the lack of impact of foreign aid on income inequality, those variables do not provide a convincing explanation. Misallocation of resources might also explain this poor link as donor countries frequently stipulate that recipient one's contract with firms and consultants from such countries. The income earned by foreigners will not show up in panel data, and if it did, it might even lead to the conclusion that aid increases inequality as aid may be spent on projects that have no productive value. However, they concluded that foreign aid is able to improve income distribution in the presence of good institutions.

Shaifiullah (2011) presented the theoretical perspectives of foreign aid's impact on income distribution and provided empirical evidence using a panel of 94 countries over 20 years (1989-2008). He conducted a panel analysis involving either a random or a fixedeffects model. The data, however, showed evidence to the contrary that aid causes small reductions in inequality. The findings are similar to those in recent studies on the topic. He also found that trade and the share of the population under the age of 15 worsen inequality. Theoretically and practices showed that corruption is the main problem in aid delivery management. Foreign aid always leads to rent-seeking. For example, based on a model of rent-seeking, Svensson (2000) showed foreign aid and windfall increased rentseeking since the powerful groups manipulate the political system to implement favourable transfers, regulations and other redistributive policies. He found that foreign aid has a positive impact on corruption in democratic governments.

Herzer and Nunnenkamp (2012) examined the long-run effect of foreign aid on income inequality for 21 recipient countries using panel co-integration techniques to control for omitted variable and endogeneity bias. They indicated that aid exerts an inequality increasing effect on income distribution. In addition, Tezanos et al. (2013) restricted their sample to Latin American and Caribbean countries. In contrast to the other studies, their research is based on growth theory and growth rate of GDP per capita of the population in the poorest, compared to the general per capita growth rate.

Ali and Ahmad (2013) explored the impact of aid on income inequality in Pakistan for the period 1972-2007 using Johansen Co-integration Test. They found that income inequality increased the impact of official aid in Pakistan in the long run. They concluded that financial resources received in terms of foreign aid had not been used for development; rather, these funds may have been sidetracked to unproductive activities. Therefore, the aid inflows could not add to the growth of Pakistan economy, employment generation and therefore increased the income inequality in the economy. Recently, Pham (2015) analyzed the impact of foreign aid on income inequality in Sub- Saharan Africa by employing a large dataset covering twenty-seven countries in Sub Saharan Africa over the period 1990-2011. He found the evidence of an inequality increasing effect of foreign aid in Sub-Saharan Africa. However, this effect can reverse when corruption is controlled.

In sum, all the previous studies analyzed the impact of aggregate foreign aid on income inequality. Nevertheless, none of the studies focuses on the impact of disaggregates foreign aid. Therefore, this study makes a significant contribution to the existing body of literature on the impact of foreign aid on income inequality of aid recipient countries by focusing on the impact of the sectoral allocation of aid (social aid, economic aid, production aid and multi aid) on income inequality of aid recipient countries. There are some of the previous studies, such as Svensson (2000), Calderon and Gradstein (2009), Pham (2015) found the significant impact of the quality institution to the impact of foreign aid on income inequality. However, these studies only used the corruption index as a proxy to the quality of the institution. Thus, this study fills the gap by utilizing the law and order 
index to proxy the quality of institutions. In addition, this study adds a novelty to previous studies by including the interaction terms of sectoral allocation of foreign aid with law and order in income inequality regression.

\section{METHODOLOGY AND DATA}

\subsection{Data}

The data used in the estimation of the impact of the sectoral allocation of aid (SAA) and law and order (institutions quality) on income inequality are utilized from a panel dataset of 49 foreign aid recipient countries for the period of 1995-2017. The Gini indices were sourced from the online database of the Standardized World Income Inequality Database (SWIID). The data of the sectoral allocation of aid (SAA) were downloaded from Organization of Economic Corporation and Development (OECD) in the Development Assistance Committee (DAC) under the Credit Reporting System (CRS) (2017). The data of real per capita GDP and value-added in the agricultural sector are developed from the World Development Indicator (WDI, 2017) online database. Finally, the quality of institutions index, law and order were compiled from ICRG (2017).

\subsection{Model Specification}

Empirically examining the relationship between foreign aid and income inequality, this study estimates the variants of the following specification. This study postulates the basic empirical specification model suggested by Simon Kuznet (1995), Alderson and Nielson (1999), Huber et al. (2006), Chong et al. (2009) and Layton and Nielson (2009). This study uses the following model to estimate the effect of foreign aid on income inequality:

$$
I N E Q=f(G D P C C, A V A, S A A, I N S)
$$

Where $I N E Q$ represents income inequality, as proxied by the Gini index. GDPCC refers to the real per capita gross domestic product, $A V A$ stands for agricultural value added as percentages of GDP, $S A A$ is the sectoral allocations of aid, and INS stands for institutions quality (ICRG indicators). The sectoral allocations of foreign aid will show in relative to GDP. This study estimates the income inequality (INEQ) function as follows:

$$
\begin{aligned}
\operatorname{In} I N E Q_{i, t}= & \beta_{0}+\beta_{1} \operatorname{In} I N E Q_{i, t-1}+\beta_{2} \operatorname{In} G D P P C_{i, t}+\beta_{3} A V A_{i, t}+\beta_{4} \operatorname{In} S A_{i, t}+ \\
& \beta_{5} \operatorname{In} E A_{i, t}+\beta_{6} \operatorname{In} P A_{i, t}+\beta_{7} \operatorname{In} M A_{i, t}+\beta_{8} \operatorname{In} I N S_{i, t}+\eta_{i}+\mu_{t}+\xi_{i, t}
\end{aligned}
$$

To estimate the impact of the quality of institutions on the effect of sectoral allocations of foreign aid on income inequality, this study includes the variable of the interaction terms between sectoral allocations of foreign aid and institutions quality in the estimation model. Therefore, the estimated equation of income inequality INEQ turns to a non-linear form due to the multiplicative terms that represent the interaction term between sectoral allocations of foreign aid and quality of institutions as follows:

$$
\begin{aligned}
\operatorname{In} I N E Q_{i, t}= & \beta_{0}+\beta_{1} \operatorname{In} I N E Q_{i, t-1}+\beta_{2} \operatorname{In} G D P P C_{i, t}+\beta_{3} A V A_{i, t}+\beta_{4} \operatorname{In} S A_{i, t}+ \\
& \beta_{5} \operatorname{In} E A_{i, t}+\beta_{6} \operatorname{In} P A_{i, t}+\beta_{7} \operatorname{In} M A_{i, t}+\beta_{8} \operatorname{In} I N S_{i, t}+\beta_{9} \operatorname{In}(S A A * \\
& I N S)_{i, t}+\eta_{i}+\mu_{t}+\xi_{i, t}
\end{aligned}
$$


Where $\operatorname{In} I N E Q_{i, t-1}$ denotes the logarithm of the lag of income inequality proxies by GINI index. The expected sign of the coefficient of this variable is positive. Normally, income inequality in the present year is strongly influenced by the income inequality of the previous year. In $G D P P C_{i, t}$ refers to the real per capita gross domestic product (GDP) of aid recipient countries. The dominating theory regarding economic development and income inequality is Simon Kuznets' (1995) inverted U-shaped curve. The shape of the curve represents that income inequality increases as per capita income increases at lower levels of development.

On the other hand, at higher levels of development, income inequality decreases as per capita income increases. This study compiles dataset from developing countries that receive foreign aid. This study predicts that real per capita GDP will decrease income inequality. Thus, the coefficient of this variable is expected to have a negative sign. $A V A_{i, t}$ stands for the values added to the agricultural sector (as percentages of GDP). This variable is included in the model income inequality to reflect the employment in the agricultural sector. Alderson and Nielson (1999) argued that the decreasing proportions of employment in agriculture would increase inequality. Therefore, increased employment in agriculture will lead to a reduction in income inequality. Because of the limited data on employment in agriculture, this study uses the data of agricultural value-added as a percentage of GDP. This variable is expected to have a negative relationship with income inequality.

$\operatorname{In}(S A A)_{i, t}$ is the ratio of sectoral allocation of aid to GDP. It consists of four sectoral allocations of foreign aid: (a) aid to social infrastructure and services sectors or social aid (SA); (b) aid to economic infrastructure and services sectors or economic aid (EA); (c) aid to production infrastructure and services sectors or production aid (PA); and (d) aid to multi-infrastructure and services sector or multi-aid (MA). This study assumes all sectoral allocations of aid may have a negative sign of income inequality by improving the living standard, health, and education. $\operatorname{In}(I N S)_{i, t}$ refers to the quality of institutions, which proxy by which law and order (LAO). This index was taken from ICRG (2017), compiled by the Political Risk Services group. The higher value of the indicators reflects better institutional quality (PRS Group, 2017; Herzer and Morrissey, 2011). This indicator is expected to have a negative relationship with income inequality. This implies that the good quality of institutions will lead to a decrease in income inequality.

$\operatorname{In}(S A A * I N S)$ the interaction terms of four sectoral allocations of foreign aid with law and order. These variables are included in this analysis to determine whether the quality of the institutions is a complementary factor for the effectiveness of sectoral allocations of foreign aid on income inequality or not. In other words, it signifies whether law and order (quality of the institutions) influence the impact of $S A A$ on income inequality in aid recipient countries. If the interaction variable is statistically significant, this implies that the quality of institution has a significant influence on the marginal effect of $S A A$ or its effects on income inequality. Thus, this variable is expected to have a negative relationship with income inequality, implying that an increase in quality of institutions would increase the effect of SAA on reducing income inequality.

\subsection{Econometric Methodology}

This study uses two steps system generalize method of moment (Sys-GMM) method to investigate the impact of foreign aid on income inequality. The rationale using the dynamic panel data approach Sys-GMM was the cross-country findings likely to be biased due to common problems of simultaneity and reverse causation that may arise because income inequality may be affected by foreign aid that may be driven by income inequality. 
Furthermore, the country-specific factor is not directly eliminated but controlled by appropriate instrumental variables (lag differences of the corresponding variables), and this method confirmed that is no correlation between the differences of the independent variables and the country-specific effect.

However, the additional moment conditions of the sys-GMM estimator do not come without a cost. The instruments for the level equations are valid as long as they are orthogonal to the fixed effects. In addition, the sys-GMM may suffer from the weak instrument problem, particularly when the time series are large and substantial unobserved heterogeneity exists (Hayakawa, 2006; Bun and Windmeijer, 2010). Another potential deficiency of the sys-GMM estimators is that the number of internal instruments grows quadratically as the number of time taken increases. To this problem, Roodman (2009) indicated that instrument proliferation could over-fit endogenous variables, biasing coefficient estimates and weakening the Hansen test of the instruments' joint validity. Therefore, this study reduces the instrument count by 'collapsing' the instruments as suggested by Roodman (2009), which is superior to simply restricting the lag ranges. This study uses the sys-GMM method by Roodman (2009) considering the lag of independence variable as instruments in estimating the impact of foreign aid and quality of institutions on economic growth.

A basic outline of the sys-GMM method is presented below. For ease of exposition, each section of the system is presented separately, although, as mentioned above, the entire system is estimated jointly.

\subsection{System in First Differences}

This study eliminates the unobserved country-specific effects by specifying the regression equation in first differences:

$$
y_{i, t}-y_{i, t-1}=\left(y_{i, t-1}-y_{i, t-2}\right) \emptyset+\left(X_{i, t}-X_{i, t-1}\right) Y_{1}+\left(S_{i, t}-S_{i, t-1}\right)\left(\varepsilon_{i, t}-\varepsilon_{i, t-1}\right)
$$

For this specification, the choice of instruments requires dealing with two problems. First, the possible endogeneity of the explanatory variables, $Z=[X S]$, which is reflected in the correlation between these variables and the error term. Second, the new error term $\left(\varepsilon_{i, t}-\varepsilon_{i, t-1}\right)$, is correlated by constructed it with the differenced lagged dependent variable, $\left(y_{i, t-1}-y_{i, t-2}\right)$. According to this procedure, this study allows for the possibility of simultaneity and reverses causation; instead of assuming strict exogeneity (i.e. no correlation between the explanatory variables and the error term at all leads and lags). We adopt the more flexible assumption of weak exogeneity with the current explanatory variables being affected by the past and current realizations of the dependent variable but not by its future innovations. Under the assumptions that: (a) the error term, $\varepsilon$, does not exhibit serial correlation; and (b) the explanatory variables are weakly exogenous, the following moment conditions apply:

$$
\begin{aligned}
& E\left[y_{i, t-s} *\left(\varepsilon_{i, t}-\varepsilon_{i, t-1}\right)\right]=0 ; \text { for } \mathrm{s} \geq 2, \text { and } t=, \ldots, T \text { and } \\
& E\left[Z_{i, t-s} *\left(\varepsilon_{i, t}-\varepsilon_{i, t-1}\right)\right]=0 ; \text { for } \mathrm{s} \geq 2, \text { and } t=, \ldots, T
\end{aligned}
$$

The GMM-IV estimator is based on the moment conditions and is known as the differences estimator. Although asymptotically consistent, this estimator has low asymptotic precision and large biases in small samples, which lead to the need to complement it with the regression equation in levels. 


\subsection{System in Levels}

For this part of the system, the country-specific factor is not directly eliminated but must be controlled for by the use of instrumental variables. The appropriate instruments for the regression in levels are the lagged differences of the corresponding variables if the following assumption holds. Although there may be a correlation between the levels of the right-hand side variables and the country-specific effect, there is no correlation between the differences between these variables and the country-specific effect. This assumption results from the following stationarity property:

$$
E\left[y_{i, t+p} * \eta i\right]=E\left[y_{i, t+q} * \eta i\right] \text { and } E\left[Z_{i, t+p} * \eta i\right]=E\left[Z_{i, t+q} * \eta i\right] ; \forall p \text {. }
$$

Therefore, the additional moment conditions for the second part of the system (the regression in levels) are given by the following equations:

$$
\begin{aligned}
& E\left[\left(y_{i, t-s}-y_{i, t-s-1}\right) *\left(\eta i-\varepsilon_{i, t}\right)\right]=0 ; \text { for } s=1, \text { and } \\
& E\left[\left(Z_{i, t-s}-Z_{i, t-s-1}\right) *\left(\eta i-\varepsilon_{i, t}\right)\right]=0 ; \text { for } s=1 .
\end{aligned}
$$

Using the moment conditions above, we employ a sys-GMM procedure to generate consistent estimates of the parameters of interest. The weighting matrix for the GMM estimation can be any symmetric, positive definite matrix, and we obtain the most efficient GMM estimator if we use the weighting matrix corresponding to the variance-covariance of the moment conditions. Since this variance-covariance is unknown, Arellano and Bond (1991) and Arellano and Bover (1995) suggested the following two-step procedure. First, assume that the residuals, $\varepsilon_{i, t}$, are independent and homoscedastic both across countries and over time. This assumption corresponds to a specific weighting matrix that is used to produce first-step coefficient estimates. This study constructs a consistent estimate of the variance-covariance matrix of the moment conditions with the residuals obtained in the first step and uses this matrix to re-estimate our parameters of interest (i.e. second-step estimates).

Asymptotically, the second-step estimates are superior to the first-step estimates, so far as efficiency is concerned. In this study, the moment conditions are applied such that each of them corresponds to all available periods, as opposed to each moment condition corresponding to a particular time period. In the former case, the number of moment conditions is independent of the number of time periods, whereas, in the latter case, it increases more than proportionally with the number of time periods. Most of the literature dealing with GMM estimators applied to dynamic models of panel data treats the moment conditions as applying to a particular time period.

\section{EMPIRICAL RESULTS}

Table 1 presents the empirical results of the impact of the interaction term between the sectoral allocation of foreign aid and quality of institutions (law and order) on income inequality. 
Table 1. Impact of sectoral allocation of foreign aid (SAA) and law and order on income inequality

\begin{tabular}{|c|c|c|c|c|}
\hline \multirow[b]{2}{*}{$\begin{array}{l}\text { Independent } \\
\text { Variables }\end{array}$} & \multicolumn{4}{|c|}{ Dependent Variable: Gini Index (INEQ) } \\
\hline & $\begin{array}{l}\text { Model 1a } \\
\text { (SA*LAO) }\end{array}$ & $\begin{array}{l}\text { Model 1b } \\
\text { (EA*LAO) }\end{array}$ & $\begin{array}{l}\text { Model 1c } \\
\left(\text { PA*LAO) }^{*}\right.\end{array}$ & $\begin{array}{l}\text { Model 1d } \\
\text { (MA*LAO) }\end{array}$ \\
\hline Constant & $\begin{array}{l}0.996 \\
(1.34)\end{array}$ & $\begin{array}{l}1.965^{\star \star \star} \\
(2.72)\end{array}$ & $\begin{array}{l}1.140^{* *} \\
(2.53)\end{array}$ & $\begin{array}{l}0.868^{* * *} \\
(2.88)\end{array}$ \\
\hline Ginit $_{t-1}$ & $\begin{array}{l}0.850^{* \star *} \\
(15.85)\end{array}$ & $\begin{array}{l}0.777^{* * *} \\
(9.61)\end{array}$ & $\begin{array}{l}0.851^{* * *} \\
(15.82)\end{array}$ & $\begin{array}{l}0.876^{\star * *} \\
(15.50)\end{array}$ \\
\hline $\begin{array}{l}\text { Real per capita } \\
\text { GDP }\end{array}$ & $\begin{array}{l}-0.043 \\
(-0.66)\end{array}$ & $\begin{array}{l}-0.121^{*} \\
(-1.81)\end{array}$ & $\begin{array}{l}-0.055 \\
(-1.24)\end{array}$ & $\begin{array}{l}-0.038 \\
(-1.49)\end{array}$ \\
\hline $\begin{array}{l}\text { Agricultural value } \\
\text { added }\end{array}$ & $\begin{array}{l}-0.040 \\
(-0.48)\end{array}$ & $\begin{array}{l}-0.138^{* *} \\
(-1.89)\end{array}$ & $\begin{array}{l}-0.059^{*} \\
(-1.75)\end{array}$ & $\begin{array}{l}-0.043 \\
(-1.61)\end{array}$ \\
\hline Social aid (SA) & $\begin{array}{l}-0.056^{* * *} \\
(-3.14)\end{array}$ & $\begin{array}{l}-0.055^{* *} \\
(-1.99)\end{array}$ & $\begin{array}{l}-0.036^{*} \\
(-1.69)\end{array}$ & $\begin{array}{l}-0.049^{* * *} \\
(-2.65)\end{array}$ \\
\hline Economic aid (EA) & $\begin{array}{l}0.007 \\
(0.45)\end{array}$ & $\begin{array}{l}0.008 \\
(0.44)\end{array}$ & $\begin{array}{l}0.001 \\
(0.07)\end{array}$ & $\begin{array}{l}0.005 \\
(0.40)\end{array}$ \\
\hline Production aid (PA) & $\begin{array}{l}0.024 \\
(0.83)\end{array}$ & $\begin{array}{l}0.017 \\
(0.88)\end{array}$ & $\begin{array}{l}0.021 \\
(1.35)\end{array}$ & $\begin{array}{l}0.024^{*} \\
(1.79)\end{array}$ \\
\hline Multi aid (MA) & $\begin{array}{l}-0.001 \\
(-0.05)\end{array}$ & $\begin{array}{l}-0.017 \\
(1.00)\end{array}$ & $\begin{array}{l}-0.004 \\
(-0.29)\end{array}$ & $\begin{array}{l}0.0003 \\
(0.02)\end{array}$ \\
\hline $\begin{array}{l}\text { Law and order } \\
(\text { LAO) }\end{array}$ & $\begin{array}{l}-0.091^{* *} \\
(-2.41)\end{array}$ & $\begin{array}{l}-0.062 \\
(-1.31)\end{array}$ & $\begin{array}{l}-0.063^{* * *} \\
(-2.64)\end{array}$ & $\begin{array}{l}-0.054^{*} \\
(-1.81)\end{array}$ \\
\hline SAA x LAO & $\begin{array}{l}-0.072^{* * *} \\
(-2.60)\end{array}$ & $\begin{array}{l}-0.010 \\
(0.36)\end{array}$ & $\begin{array}{l}-0.060 \\
(-1.63)\end{array}$ & $\begin{array}{l}-0.051^{* *} \\
(-2.19)\end{array}$ \\
\hline No. of obs. & 185 & 185 & 185 & 185 \\
\hline Wald test & $\begin{array}{l}632.19 \\
(0.000)\end{array}$ & $\begin{array}{l}162.65 \\
(0.000)\end{array}$ & $\begin{array}{l}645.00 \\
(0.000)\end{array}$ & $\begin{array}{l}887.35 \\
(0.000)\end{array}$ \\
\hline Wald test & $\begin{array}{l}632.19 \\
(0.000)\end{array}$ & $\begin{array}{l}162.65 \\
(0.000)\end{array}$ & $\begin{array}{l}645.00 \\
(0.000)\end{array}$ & $\begin{array}{l}887.35 \\
(0.000)\end{array}$ \\
\hline Hansen test & $\begin{array}{l}30.83 \\
(0.475)\end{array}$ & $\begin{array}{l}25.47 \\
(0.746)\end{array}$ & $\begin{array}{l}31.77 \\
(0.625)\end{array}$ & $\begin{array}{l}33.33 \\
(0.549)\end{array}$ \\
\hline $\mathrm{AR}(1)$ test & $\begin{array}{l}-0.91 \\
(0.365)\end{array}$ & $\begin{array}{l}-1.70 \\
(0.089)\end{array}$ & $\begin{array}{l}-1.69 \\
(0.091)\end{array}$ & $\begin{array}{l}-1.39 \\
(0.166)\end{array}$ \\
\hline $\mathrm{AR}(2)$ test & $\begin{array}{l}-0.05 \\
(0.962)\end{array}$ & $\begin{array}{l}0.81 \\
(0.417)\end{array}$ & $\begin{array}{l}-0.41 \\
(0.678) \\
\end{array}$ & $\begin{array}{l}-0.02 \\
(0.984) \\
\end{array}$ \\
\hline
\end{tabular}

Model 1a, 1b, 1c and 1d in Table 1depicted the estimated coefficients of the interaction terms between sectoral allocations of foreign aid with law and order (LAO). The empirical results in Model 1a and 1d show that the interaction term of social aid (SA) and multi aid (MA) with law and order (LAO) had a negative and significant impact on income inequality at 1 and 5 percent of significance level, respectively. These findings suggested that law and order have a significant influence on the impact of social aid (SA) and multi aid (MA) on reducing income inequality of the recipient countries. This finding supports Svensson (2000), Calderon et al. (2009) Calderon and Gradstein (2009) and Pham (2015) that foreign aid improved income distribution in the presence of good institutions.

Moreover, social aid (SA) exhibited a negative and significant impact on income inequality in selected aid recipient countries. This finding suggests that social aid is effective in reducing income inequality in aid recipient countries. In addition, as control variables, real per capita gross domestic product and agricultural value-added are found to have a reducing income inequality effects. While the first lag of the Gini index shows an increasing inequality effect, this finding implies that income inequality of the previous year has strong and positively correlated with income inequality within the period of the study. 
The Wald test displayed that the coefficients were jointly significant at 1 percent significance level. All the models passed the Hansen test as it failed to reject the null hypothesis that the instruments used were not correlated with the residuals (Beck \& Levine, 2004). In addition, the p-values of AR (1) were less or greater than 5 percent for some regressions. These results showed that the residuals were correlated at the $1^{\text {st }}$ order conditions for some regressions, but not for other regressions. However, this study observed that the residuals were not correlated at the $2^{\text {nd }}$ order conditions when $p$-values of AR (2) test were greater than 5 percent significance level for all regressions. Thus, both Hansen and Arrelano-Bond statistics verified that the instruments used had no-overidentifying restriction, and the residuals were independent.

\section{CONCLUSION}

This study contributed to the literature on the sectoral impact allocation of foreign aid and quality of institution (law and order) on income inequality. This study found that the interaction of social aid and multi aid with law and order exhibited a negative and significant impact on income inequality. This finding indicated that a good law and order system is complementary to social aid and multi aid in closing the income gap or income inequality of the aid recipient countries. Hence, development practitioners and policymakers should take into consideration the quality of an institution of recipient this aspect of their government system when deciding to receive foreign aid. In addition, recipient countries should determine their development goals and priorities and strategies for economic development, improve quality of institutions by enhancing law and order to make foreign aid fully effective for successful and sustained economic and social development. All donors should take good quality law and order as pre-requisite or benchmark in giving aid to developing countries in order to ensure that foreign aid achieves the development goals.

\section{REFERENCES}

Alderson, A. S., \& Nielsen, F. (1999). Income inequality, development, and dependence: A reconsideration. American Sociological Review, 606-631.

Ali, S., \& Ahmad, N. (2013). A time series analysis of foreign aid and income inequality in Pakistan. Global Journal of Management and Business Research Economics and Commerce, 13(5), 10-20.

Arellano, M., \& Bond, S. (1994). Some tests of specifications for panel data: Monte Carlo evidence and an application to panel data to employment equations. Review of Economic Studies, 58(2), 277-297.

Beck, T., Demirgüç-Kunt, A., \& Levine, R. (2004). Finance, inequality, and poverty: Cross-country evidence. The World Bank.

Bjornskov, C. (2010). Do elites benefit from democracy and foreign aid in developing countries, Journal of Development Economics, 92(2), 115-124.

Blundell, R., \& Bond, S. (1998). Initial conditions and moment restrictions in dynamic panel models. Journal of Econometrics, 87(1), 115-143.

Boone, P. (1994). The impact of foreign aid on savings and growth. Centre for Economic Performance Working Paper No. 1265. London School of Economics, London.

Boone, P. (1996). Politics and the effectiveness of foreign aid. European Economic Review, 40(2), 289-329.

Bornschier, V., Chase-Dunn, C., \& Rubinson, R. (1978). Cross national evidence of the effects of foreign investment and aid on economic growth and inequality: a survey of findings and a reanalysis. American Journal of Sociology, 84(3), 651-683.

Bourguignon, F, Levin, V., \& Rosenblatt, D. (2009). International redistribution of income. World Development, 37(1), 1-10.

Brautigam, Deborah A., \& Knack, S. (2004). Foreign aid, institutions, and governance in sub-Saharan Africa. Economic Development \& Cultural Change, 52(2), 255-285.

Burill, D. (2007). Modelling and interpreting interactions in multiple regression. Available at http://www.minitab.com 
Burnside, C., \& Dollar, D. (2004). Aid, policies and growth: reply. The American Economic Review, 94(3), 774780.

Burnside, C., \& Dollar, D. (2000). Aid, policies, and growth. American Economic Review, 90(4), 847-868.

Burnside, C., \& Dollar, D. (1998). Aid, the incentive regime, and poverty reduction. Policy Research Working Paper 1937. World Bank, Development Research Group, Washington D.C.

Calderon, C, Chong, A., \& Gradstein, M. (2009). Can foreign aid reduce income inequality and poverty? Public Choice, 140 (1), 59-84.

Chenery, H., \& Strout, A. (1966). Foreign assistance and economic development. The American Economic Review, 56(4), 679-733.

Chenery, H. B., \& Carter, N. G. (1973). Foreign Assistance and development performance, 1960-1970. American Economic Association, 63(2), 459-468.

Chong, A. (2004). Democracy, persistence, and inequality: is there a political Kuznet's curve?. Economics and Politics, 16(2), 189-212.

Chong, A., Gradstein, M., \& Calderon, C. (2009). Can foreign aid reduce income inequality and poverty?. Public Choice, 140(1-2), 59-84.

Dreher, A., \& Gaston, N. (2007). Has globalization increased inequality? Review of International Economics, 16(3), 516-536.

Doucouliagos, H., \& Paldam, M. (2010). Conditional aid effectiveness: a meta-study. Journal of International Development, 22(4), 391-410.

Durbarry, R., Gemmell, N., and Greenaway, D. (1998). New Evidence on the impact of foreign aid on economic growth. CREDIT Research Paper 98/9.

Erikson, F. (2005). Aid and development: Will it work this time? International Policy Network 2005 Great Britain: Hanway Print Centre.

Herzer, D., \& Morrissey, O. (2011). Long-Run Aid Effectiveness. CSAE Conference 2011, Economic Development in Africa.

Herzer, D., \& Nunnenkamp, P. (2012). The effect of foreign aid on income inequality: Evidence from panel cointegration. Structural Change and Economic Dynamics, 23(3), 245-255.

Islam, Anisul (1992). Foreign aid and economic growth: an econometric study of Bangladesh. Applied Econometrics, 24(5), 541-544.

Khieu, S. (2013). Essays on the impact of aid and institutions on income inequality and human welfare. (Doctor of Philosophy in Public Policy), Georgia State University.

Layton, T., \& Nielson, D. (2009). Aiding Inequality: the effect of foreign aid on income inequality. Brigham Young University.

Nelson, R. (1956). A theory of the low-level equilibrium trap in underdeveloped economies. American Economic Review, 46(5), 894-908.

Organization for Economic Co-operation and Development (OECD). (n.d.a). Aid statistics. Official development assistance - definition and coverage, Available Online: http://www.oecd.org/dac/stats/officialdevelopmentassistancedefinitionandcoverage.htm\#Definition [Accessed 30th November 2017]

Organization for Economic Co-operation and Development (OECD). (n.d.b). CPA data series by sector, Available Online: http://www.oecd.org/development/aid-architecture/cpa.htm [Accessed 30th November 2017]

Organization for Economic Co-operation and Development (OECD).(n.d.c). Development Co-operation Directorate (DCD-DAC). DAC members, Available Online: http://www.oecd.org/dac/dacmembers.htm [Accessed 30th November 2017]

Organization for Economic Co-operation and Development (OECD). (n.d.d). The Paris Declaration on Aid Effectiveness and the Accra Agenda for Action [pdf] Available Online: http://www.oecd.org/dac/effectiveness/parisdeclarationandaccraagendaforactionfullrelateddocumentati o n.htm [Accessed 11th November 2013]

Organization for Economic Co-operation and Development (OECD), Query Wizard for International Development Statistics. (n.d.e). QWIDS data query, Available Online: http://stats.oecd.org/qwids/ [Accessed 2 December 2017]

Cassen, R. (1994). Does Aid Work, Second Edition. Oxford: Clarendon Press.

Rodrik, D., Subramanian, A., and Trebbi, F. (2004). Institutions rule: The primacy of institutions over geography and integration in economic development. Journal of Economic Growth, 9(6), 131-165.

Roodman, D. (2004). The anarchy of numbers: aid, development, and cross-country empirics. CGD Working Paper 32. Center for Global Development, Washington, D.C.

Roodman, D. (2007). The anarchy of numbers: aid, development and cross-country empirics. The World Bank Economic Review, 21(2), 255-277.

Sachs, J. D., \& Warner, A. (1995). Economic reform and the process of global integration. Brooking Papers on Economic Activities, 26(1), 1-118.

Sachs, J. D. (2005). The end of poverty: economic possibilities for our time, The Penguin Press: New York. 
Appendix AShafiullah, M. (2011).Foreign Aid and its Impact on Income Inequality. International Review of Business Research Papers, 7(2), 91-105.

Kuznets, S. (1955). Economic growth and income inequality. The American Economic Review, 45(1), 1-28.

Singh, R. D. (1985). State Intervention, foreign economic aid, savings and growth in LDCS: some recent evidence. KYKLOS, 38(2), 216-232. 